\title{
Measuring R\&D Performance Using Data Envelopment Analysis (DEA): Case Indonesia
}

\author{
Indri J. Asmara, Elmi Achelia, Nani G. Simamora, and Bagus Sartono
}

\begin{abstract}
Research institutions play a role in creating science and innovation. Public Research Institution (PRI) as government-funded research institutes has been recognized as a strategic actor which has responsibility for encouraging researchers in producing efficient qualified research. An Indonesian PRI conducts research activities in basic, applied and experimental research with various fields of science such as life science, earth science, engineering science, and social and humanities science. This paper aims to provide an overview of PRI's R\&D performance by measuring efficiency in $R \& D$ performance using the Data Envelopment Analysis (DEA) method in 35 research units that were used as objects in a government R\&D institution in Indonesia. DEA calculates input and output in the $R \& D$ unit which has 1,735 researchers and output in each field of science. The result shows that R\&D performance was very different between the field of science and age group of researchers. The conclusion is that most of the efficiency created by young researchers. And the field of science that has near efficiency compared to other fields of science is engineering.
\end{abstract}

Index Terms-R\&D performance, efficiency, DEA, researcher.

\section{INTRODUCTION}

Research institutions play a role in creating science and innovation. Innovation sustainability in the long term is part of knowledge-based economic development, with the capability and capability of qualified human resources, knowledge-based economic development will be able to increase economic growth. Development of science and technology in Indonesia which is based on research and development (R\&D) aimed at producing various research products that benefit the community and stakeholders. "Scientific institutions are complex and dynamic organizations, whose main purpose is producing and disseminating scientific research within national economic systems to generate inventions and innovations, which are more and more important to the competitiveness of countries" [1]. Like in many countries "PRIs or GRIs in Indonesia have played a pivotal role in national $R \& D$ as a key player of the national innovation system (NIS) or as a major component of the triple helix model of innovation system [2].

Manuscript received March 15, 2019; revised May 23, 2019. This work was supported in part of research activity by the Center for S\&T development studies, Indonesian Institute of Sciences. And disseminate by this publication, which has funded by Ministry of research technology and higher education of Indonesia.

Indri J. Asmara, Elmi Achelia, Nani G. Simamora are with Indonesian Institute of Sciences, Jakarta, 12710 Indonesia (e-mail: indr003@ lipi.go.id or_indri.asmara@gmail.com,_elmiachelia@gmail.com, grcsimamora@gmail.com).

Bagus Sartono is with Bogor Agricultural University, Bogor, 16680 Indonesia (email: bagusco@gmail.com)
Public Research Institutions (PRIs) as Government-funded Research Institutes (GRIs) are responsible for encouraging researchers to produce research, publications of research results, and to disseminate the results so that it can benefit the community in an effective and efficient way. PRIs acknowledgement of knowledge creation and diffusion as strategic actor has been recognized. In the case of Indonesia, creation and commercialization of PRI's research results are critical areas of Indonesian science, technology and innovation policy [3].

OECD (2002) defines R\&D activities as "Research and experimental development $(\mathrm{R} \& \mathrm{D})$ that comprises creative work. It is carried out on a systematic basis in order to increase the stock of knowledge, include knowledge of man, cultures and society, and the use of this stock of knowledge to devise new applications"[4]. In this case, R\&D activities are not only intended to increase knowledge or knowledge but also develop that knowledge so that it can be applied and utilized. Therefore R\&D activities are oriented to needs or real problems or are demand-driven [3]. "R\&D activities are key and basic components to development of science and technology (S\&T), and also have important role in developing and sustaining the growth of the national economy and corporate business" [5]. Investment in R\&D is the most critical determinants in boosting scientific and technological progress. In private organization, R\&D resources that are efficiently utilise, may attain higher progress and economic growth in the firms [6].

Government R\&D institutions according to Demir [7] play an important role in the national innovation system. This is because most $R \& D$ institutions in the most developed or developing countries are in the government sector or the R\&D activities are funded by the government. In the NSF report (2016) stated that the accumulation of $R \& D$ activities in the government sector is because for strategic matters, especially aimed the public interest. To be strategic matters, R\&D Institutions should have the following capacity, first the capacity to absorb science and technology that originates from the outside [3]. The capacity to absorb science and technology from the outside is indicated, among others, from accessibility to various sources of science and technology information so that it is less likely to experience overlapping research and efficiency in resource use. Second is the capacity in conducting $R \& D$ or $R \& D$ capacity is reflected in the quality of R D and output produced and the relevance of technology that is appropriate and meets the real needs of users.

Based on the definition of $R \& D$ there are differences in R\&D performance according to their classification. First, based on the type of institution and $R \& D$ activities undertaken are classified as follows: a. R\&D activities in 
R\&D institutions; b. R\&D activities that are contracted out, collaborated and placed on the system in universities; c. independent $R \& D$ laboratory; $d \mathrm{R} \& \mathrm{D}$ activities contracted to foreign institutions [8]. Second, based on the objectives of $\mathrm{R} \& \mathrm{D}$ activities, there are based on the combination of science creation activities such as basic research, fundamental research, technology development, advanced development, concept development, new product development, process development, prototyping, R\&D portfolio management, transfer technology. Besides that, they also conduct marketing activities, manage copyrights, built incubation [8]. Third, the classification is based on the size of R\&D inputs, such as budget, human resource, infrastructure, activity period. Fourth is based on research areas or topics.

Based on its management classification, Indonesia has a variety of research institutions, among research institutions managed by the government, institutions managed by universities, managed by the private sector, and managed by private non-profits. PRIs are divided into three namely independent research institutions and research institutions that are part of certain ministries and research institutions managed in the region. In several Asian countries, the government encourages universities and public research to produce output with the economy by increasing investment in research activities [3]. In Indonesia the government budget for research activities is $0.21 \%$ of GDP in 2016. While the number of researchers continues to grow, in 2018 the number of researchers in government $R \& D$ institutions is around
9,000 researchers. And the largest number of researchers that work in one of the oldest and largest research institutions in Indonesia, with 1757 people. This government R\&D institution conducts research activities in basic, applied and experimental research activities, with various fields of science such as life science, earth science, engineering science, and social and humanities science.

This paper aims to provide empirical study that provides an overview of $R \& D$ performance in the largest government $R \& D$ institutions in Indonesia and measure efficiency in R\&D performance using the DEA method in 35 research units were used as objects.

\section{LITERATURE REVIEW}

Some researchers have conducted studies on evaluating $R \& D$ performance to see institutional efficiency. "An effective $R \& D$ operation is a major source of competitive advantage in today's rapidly globalizing economy. Thus, the evaluation of R\&D performance has been the important problem for both academic interest and practical needs [8]." R\&D performance can be seen from various perspectives as shown in Table I, R\&D performance in firms [9]-[11], R\&D performance in government research institute [12], [13] based on projects [14] R\&D performance at the research unit for strategic change [2]. R\&D performance in university [15], [16] and $R \& D$ performance in the regional area [17].

TABLE I: R\&D PERFORMANCE USING DEA

\begin{tabular}{|c|c|c|c|}
\hline Paper & Performance & Input & Output \\
\hline S. Lee & $\begin{array}{l}\text { Public research institutions: } 10 \\
\text { government research institute that } \\
\text { produces } 1481 \text { projects. }\end{array}$ & budget, researcher. & Publication and patent \\
\hline M. Coccia & $\begin{array}{l}100 \text { research units divided per } \\
\text { scientific field }\end{array}$ & researcher and researcher fellow & Publication \\
\hline P. Khoshnevis & $\mathrm{R} \& \mathrm{D}$ active firms & $\begin{array}{l}\text { Expenditure, R\&D intensity, } \\
\text { employee, patent acquisition. }\end{array}$ & $\begin{array}{l}\text { Turnover per employee, Net added value } \\
\text { per employee, turn over. }\end{array}$ \\
\hline Y.J. Fenga & $\begin{array}{l}\mathrm{R} \& \mathrm{D} \text { activities in } 29 \text { universities in } \\
\text { China }\end{array}$ & $\begin{array}{l}\text { personnel structure and } \mathrm{R} \& \mathrm{D} \\
\text { expense }\end{array}$ & $\begin{array}{l}\text { published papers, number of research and } \\
\text { applied projects }\end{array}$ \\
\hline R. Li & $\begin{array}{l}\mathrm{R} \& \mathrm{D} \quad \text { Institutions in different } \\
\text { provinces ( } 30 \text { provinces) }\end{array}$ & $\begin{array}{l}\text { R\&D personnel, Intramural } \\
\text { Expenditure on } R \& D \text { (RMB one } \\
\text { hundred million). }\end{array}$ & $\begin{array}{l}\text { Scientific Papers Issued (piece), } \\
\text { Publication on Science and Technology } \\
\text { (kind), Number of Patent Applications } \\
\text { Accepted (piece), National or industry } \\
\text { standards (term) }\end{array}$ \\
\hline J. Park & $\begin{array}{l}\text { Korean } \\
\text { Public Organizations }\end{array}$ & researchers, budget, etc. & patents, papers, etc. \\
\hline Chin-Tai Chen & $\begin{array}{l}\text { the Integrated } \\
\text { Semiconductor Firms -- Case Study of } \\
\text { Taiwan }\end{array}$ & $\begin{array}{l}\text { the age of the firm, } \\
\text { paid-in-capital of the firm R\&D: } \\
\text { annual R\&D expenditure of the } \\
\text { firm, contains R\&D current } \\
\text { expenditure and R\&D capital } \\
\text { expenditure. Number of R\&D } \\
\text { employees in R\&D department } \\
\text { /or section of the firm }\end{array}$ & $\begin{array}{l}\text { annual sales of the firm, number of patents } \\
\text { approved by domestic and foreign patent } \\
\text { office }\end{array}$ \\
\hline
\end{tabular}

Evaluation of R\& D performance can use the DEA method, some researchers use the DEA method [2], [9], [11], [13]-[17], also shown in TABLE I. The Charnes data analysis concept emphasizes that DEA is a linear programming methodology that evaluates the relative performance of a decision-making unit (DMU) using a set of inputs to produce a set of outputs. With DEA, each DMU is evaluated by comparing its performance with other DMUs in the group. The use of DEA for evaluating the relative efficiencies of R\&D activities shows a good understanding of the relations between the resource utilization and the output of the different companies [8]. DEA has thus been widely used to measure R\&D efficiency at various levels, such across country comparison [18], university research, and R\&D projects.

\section{Methodology}

The technique used in data collection is to collect 
secondary data from various data sources. Data units are research units grouped into the same field of science. There were 35 research units and 1757 researchers with 36 expertises. The method used in calculating performance is DEA. The input used is the number of researchers and the output consists of articles in proceedings, articles in journals and published books.

Data Envelopment Analysis (DEA) was first introduced by Charnes, Cooper and Rhodes in 1978. Data Envelopment Analysis is a non-parametric approach that uses linear programming to determine the company's efficiency limits. DEA can be applied to Decision-Making Unit (DMU) companies or decision units. DEA can be used to measure performance and evaluate the activities of organizations such as business companies, government agencies, hospitals, educational institutions. DEA analysis is done by giving weighting to the company's input and output data to maximize the input and output ratios. The DEA model assesses the efficiency of resource use (input) to produce results (output).

$$
\text { Efficiency }=\frac{\text { Output }}{\text { Input }}
$$

The DEA model is stated in the following equation:

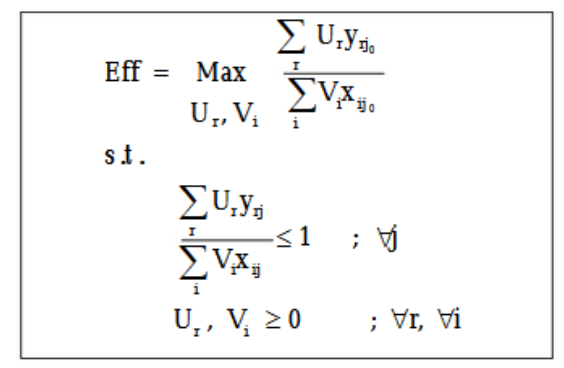

where

$y_{r j}=$ the number of output $\mathrm{r}$ produced by DMUj

$u_{r}=$ the weight given for the $r^{\text {th }}$ output

$x_{i j}=$ the number of inputs to $\mathrm{i}$ used by DMUj

$v_{i}=$ weight given for $i$-input

With this approach, the efficiency of the company is seen from the amount of output produced from the few available inputs. DEA can be used for one or more inputs and one or more outputs. Productivity can be measured by two methods, partial productivity measures and total factor productivity measures. DEA is implemented in the form of linear programming, one of which is by using $\mathrm{R}$ programming, both in the form of Constant Return to Scale (CRS) and Variable Return to Scale (VRS). CRS shows that the addition of production factors is proportional to the yield. VRS shows disproportionate changes, both in the form of increases and decreases.

In more detail, the efficiency of an organization is generally defined as the ability to produce output as much as possible with the limits of existing inputs, or vice versa can be expressed as the ability to use as little input as possible to produce targeted output. With this understanding, then the efficiency score can be expressed as the ratio between the amount of output versus input, or

$$
\text { score_efficiency }=\frac{\text { output }}{\text { input }}
$$

If there is only one type of output and one type of input process, determining the efficiency score can be done easily for each condition. Problems arise when a situation is encountered where there are several outputs or several inputs. In situations where there are $\mathrm{k}$ outputs and inputs, then we need to determine the weights for each component of the output and the input component so that the efficiency score is then defined as:

$$
\text { score_efficiency }=\frac{\sum_{i=1}^{k} w_{i} \times \text { output }_{i}}{\sum_{j=1}^{m} v_{j} \times \text { input }_{j}}
$$

$w i$ is the weight for the $\mathrm{i}$ input component $(\mathrm{i}=1,2, \ldots, k)$ and $v j$ is the weight for the $j t h$ input component $(\mathbf{j}=1,2, \ldots$, $\mathrm{m})$. Determining the weight size, and then the efficiency score, can be determined using the DEA methodology (data envelopment analysis) which has the following form of linear programming optimization model.

For a particular U unit, increase it

$$
\text { skor_efisiensi_U }=\frac{\sum_{i=1}^{k} w_{i} \times \text { output }_{i(U)}}{\sum_{j=1}^{m} v_{j} \times \text { input }_{j(U)}}
$$

with obstacles

$$
\frac{\sum_{i=1}^{k} w_{i} \times \text { output }_{i(S)}}{\sum_{j=1}^{m} v_{j} \times \text { input }_{j(S)}} \leq 1
$$

for all $S$ units (including $\mathrm{U}$ and other units) $\mathrm{w}$ and $\mathrm{v}$ are non-negative.

\section{RESUlt AND DisCUSSION}

A total of 35 R\&D units are grouped based on 4 fields of science: earth science, life science, engineering science, social and humanity science. The input of performance is the researcher. The highest number of researchers is at the Biology Research Center, Biotechnology Research Center, Chemical Research Center, Oceanographic Research Center, and the Metrology Research Center. The number of researchers from the five research centers reached $40 \%$ of all researchers. Trend of researcher based on field of science or expertise is shown in Fig. 1.

The level of researchers from the initial level starts from the junior researcher, young researchers, senior researchers, and finally the principal researcher. Increasing the level of researchers is given based on the assessment of credit numbers at a certain time period, in 2018 there were a total of 1685 researchers spread across LIPI's work units, with the largest percentage being young researchers as much as $37.03 \%$. 


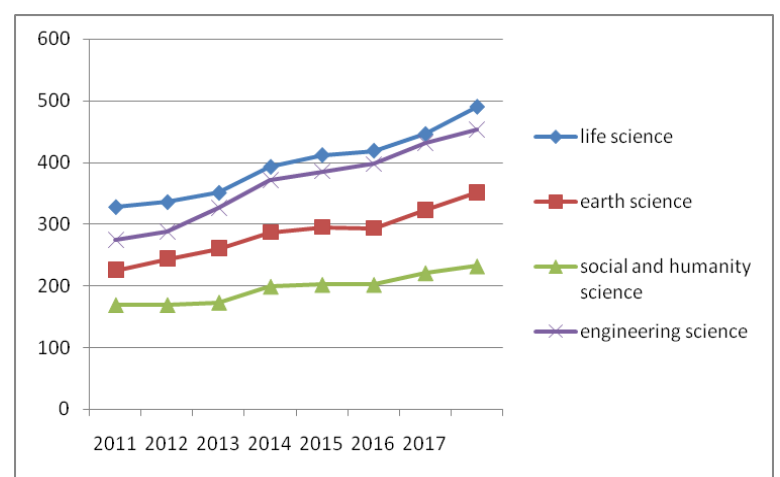

Fig. 1. Trends in number of researchers in each field of science, 2010-2017.

The functional positions of researchers must have a bachelor's degree in education. Increasing academic qualifications will also affect the level of researcher's achievement. Based on human resource database, there are researchers who have less than $1 \%$ undergraduate education background, this can occur because at the past time, there was no minimum qualification of education (bachelor) to become the junior researcher. Whereas almost half number of the researchers have postgraduate education background

The output of the DEA calculation is publication.
Publication is the main aspect that is assessed and gets a credit score for the increase in the level of researchers. Publications can be in the form of books, journals, proceedings, etc. as stated in the research manual. Based on data obtained from research output databases, publications show a positive trend with increasing numbers from year to year as shown in the Fig. 2.

TABLE II: DEA EFFICIENCY SCORES

\begin{tabular}{llrrr}
\hline \hline Tahun & $\begin{array}{l}\text { Natural } \\
\text { Science }\end{array}$ & $\begin{array}{l}\text { Earth } \\
\text { Science }\end{array}$ & $\begin{array}{l}\text { Social and } \\
\text { Humanity } \\
\text { Science }\end{array}$ & \multicolumn{2}{l}{$\begin{array}{l}\text { Engineering } \\
\text { Science }\end{array}$} \\
\hline 2010 & 0.661 & 0.406 & 0.395 & 0.522 \\
2011 & 0.830 & 0.542 & 0.444 & 0.644 \\
2012 & 0.827 & 0.688 & 0.407 & 0.687 \\
2013 & 0.940 & 0.829 & 0.473 & 0.846 \\
2014 & 0.861 & 0.937 & 0.571 & 0.859 \\
2015 & 0.901 & 0.873 & 0.793 & 0.935 \\
2016 & 0.901 & 0.854 & 0.929 & 0.935 \\
2017 & 0.980 & 0.744 & 0.849 & 1.000 \\
\hline
\end{tabular}

TABLE III: THE EFFICIENCY SCORE OF RESEARCHERS IS BASED ON AGE GROUP

\begin{tabular}{lcccccccccc}
\hline \hline Age & 2010 & 2011 & 2012 & 2013 & 2014 & 2015 & 2016 & 2017 & Total \\
\hline $20-24$ & 1.000 & 1.000 & 1.000 & 0.725 & & & 0.790 & 0.903 \\
$25-29$ & 0.806 & 0.903 & 0.935 & 1.000 & 0.951 & 0.951 & 0.951 & 0.934 & 0.929 \\
$30-34$ & 0.452 & 0.635 & 0.705 & 0.888 & 0.918 & 0.969 & 0.969 & 0.995 & 0.817 \\
$35-39$ & 0.415 & 0.494 & 0.527 & 0.656 & 0.700 & 0.835 & 0.902 & 1.000 & 0.691 \\
$40-44$ & 0.416 & 0.550 & 0.594 & 0.719 & 0.768 & 0.870 & 0.851 & 0.824 & 0.699 \\
$45-49$ & 0.556 & 0.576 & 0.577 & 0.695 & 0.829 & 0.892 & 0.922 & 0.922 & 0.746 \\
$50-54$ & 0.740 & 0.870 & 0.840 & 0.866 & 0.811 & 0.818 & 0.800 & 0.855 & 0.825 \\
$55-59$ & 0.208 & 0.362 & 0.443 & 0.617 & 0.759 & 0.891 & 0.980 & 0.977 & 0.655 \\
$60-64$ & & & & 0.091 & 0.173 & 0.269 & 0.472 & 0.659 & 0.333 \\
Grand Total & 0.574 & 0.674 & 0.703 & 0.745 & 0.751 & 0.790 & 0.852 & 0.892 & 0.748 \\
\hline
\end{tabular}

Data on R\&D performance with a unit of analysis in the form of a combination of years and field of sciences of R\&D units, the output component consists of 6 type of publications (1) global journals, (2) local journals, (3) global proceedings, (4) local proceedings, (5) local books, (6) global books and components input in the form of the number of researcher and total human resources in $R \& D$ units. Based on the above performance data, input of the number of researchers and publications then DEA produces an efficiency score is shown in Table II.

The average efficiency score for each year is 0.5 to 0.8 . The data above is the result of calculations by doing smoothing on the value of efficiency. The obvious difference is the highest efficiency value which reached 0.911 in 2016. Over a period of 8 years the R\&D efficiency score has increased, as has the efficiency score when viewed based on field of science. The R\&D unit in each field is a work unit that has a technical function, which is the unit that has the main task of carrying out research activities. Both the number of researchers and publications produced by researchers come from the R\&D unit.

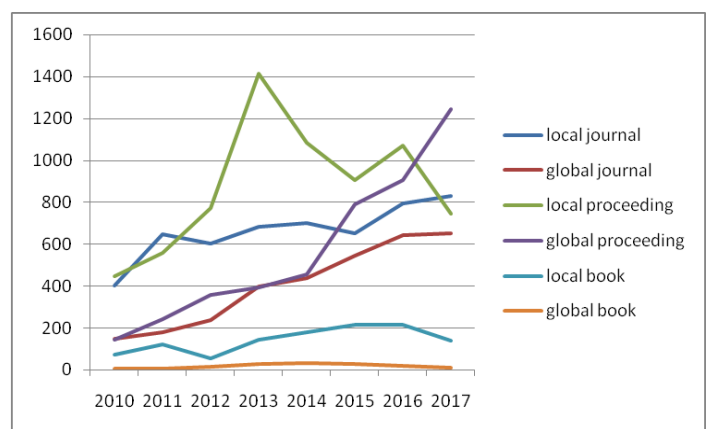

Fig. 2. The publication trend of researchers in 2010-2017.

Social and humanity science has higher efficiency score by including 6 types of publications. This means that the book is a publication output that affects the efficiency of the deployment of social and humanity science.

Efficiency score from 2010 to 2016 have increased with six types of publications. Significant improvements began in 2015. Some facts that might affect this efficiency score are: 1) 2015-2019 planning which sets the output of research in the 
form of globally indexed publications, 2) determination of performance of each $\mathrm{R} \& \mathrm{D}$ unit, 3) key performance indicators (KPI) the R\&D unit that impacts on the determination of the performance of researchers and

The highest efficiency score is at values 0.929, this efficiency value is in age group 25-29 years of researcher, so the researchers on the age group are the most productive ages. Another efficiency score that must be highlighted is 0.825 , which is the researcher that is in the age groups of 50-54 years. This is the age group of researcher that has productivity in writing books, this is shown in the simulation when only four types of publications, the efficiency value at the age of 50-54 years is 0.7 , but when the book is made into output, this age group becomes higher in productivity.

\section{CONCLUSSION}

Around $40 \%$ of the total researchers are in the R\&D units of biology, biotechnology, chemistry, oceanography and metrology. Percentage of researcher to total researcher based on the level of researchers is: $27 \%$ junior researchers, $37 \%$ young researcher, $23 \%$ senior researcher, and $13 \%$ principal researcher. From the education level of researcher, bachelor to master to $\mathrm{PhD}$ degree than the ratio will be 5: 3: 2 to total of researchers. Based on gender classification in each age group, the number of female researchers is balanced with the number of male researchers.

The most expertise of researchers is biology, aquatic science and material and metallurgy. Expertise with a small number of researchers is mathematics, fisheries, philosophy, art and culture, design, language and literature, forestry, and communication with the number of researcher in each of the expertise is less than five people. Expertise spread across several R\&D units is information and communication technology.

R\&D performance is measured using the DEA method, with input is the number of researcher and the output is six types of scientific publications that is produced over a period of 8 years (2010-2017). The R\&D efficiency score that is close to 1 is the most efficient R\&D performance. Based on the results of the DEA efficiency score, the highest efficiency score in R\&D performance in PRI is 0.929 . From year to year the value of efficiency increases, the efficiency value from 2010 to 2016 has increased with six types of publications. Significant improvement began in 2015. Engineering science is the most efficient R\&D units group among others, with significantly improvement from 2010 until 2017. What needs more attention is the R\&D unit in the fields of social science and humanity science and also earth science, because in the first few years there has been an increase in efficiency but then dropped in 2017. Performance is also seen by age group. The age group 25-29 years of researcher is the group with the highest productivity, the age group 50-54 years of researcher is the age with productivity in writing books.

\section{ACKNOWLEDGMENT}

This paper is the output of the study entitled Portrait of Human Resources as Strengthening R\&D Management: The case of one of the research institutions in Indonesia. stipulated in the integrity pact. But this still needs to be studied in depth to know for sure.

If $R \& D$ performance is based on age groups, then the $R \& D$ efficiency score from 2010 to 2017 is shown in the Table II. Dissemination of the research result with this publication has funded by Ministry of research technology and higher education of Indonesia. Thank you for all those who have supported the research to completion.

\section{REFERENCES}

[1] M. Coccia, "Measuring scientific performance of public research units for strategic change," Journal of Informetrics, vol. 2, pp.183-194, 2008

[2] M. Shapiro, "Receiving information at Korean and Taiwanese universities, industry, and GRIs," Scientometrics, vol. 90, no. 1, pp. 289-309, 2012

[3] Lakitan, "Indikator kinerja lembaga litbang di era informasi terbuka," Makalah pengarahan pada Temu Peneliti Badan Litbang dan Diklat VIII Kementerian Agama RI di Makassar tanggal 12 - 15 April 2011.

[4] OECD, "Frascati manual: Proposed standard practice for surveys on research and experimental development," The Organisation for Economic Co -operation and Development, Paris, 2002

[5] W. Zhong, W. Yuan, S. X. Li, and Z. Huang, "The performance evaluation of regional R\&D investments in China: an application of DEA based on the first official China economic census data," Omega, 2011, vol. 39, no. 4, pp. 447-55.

[6] E. C. Wang amd W. Huang, "Relative efficiency of R\&D activities: A cross-country study accounting for environmental factors in the DEA approach," Res Policy, 2007, vol. 36, no. 2.

[7] K. Demir, Human Resource Management of Government Defense $R \& D$ Organizations, Cyber Workforce Issues, 2016.

[8] K. B. Akhilesh, R\&D Management. Springer New Delhi Heidelberg, New York Dordrecht London, 2014

[9] C. Chen, C. Chien, M. Lin, and J. Wang, "Using DEA to evaluate R\&D performance of the computers and peripherals firms in Taiwan," International Journal of Business, vol. 9, no. 4, 2004.

[10] C. Chen and M. Lin, "Using DEA to evaluate R\&D performance in the integrated semiconductor firms - Case study of Taiwan," International Journal of The Computer, the Internet and Management, vol. 14. no. 3, pp. 50-59, 2006.

[11] P. Khoshnevis and P. Teirlinck, "Performance evaluation of R\&D active firm," Socio-economic Planning Sciences, vol. 61, pp. 16-28, 2018.

[12] Mulyanto, "Performance of Indonesian R\&D institutions: Influence oftype of institutions and their funding source on R\&D productivity," Technology in Society, vol. 38, pp. 148-160, 2014

[13] J. Park, J. Kim, and S. Sung, "Performance evaluation of research and business development: A case study of Korean public organizations," Sustainability, vol. 9, 2017.

[14] S. Lee and H. Lee, "Measuring and comparing the R\&D performance of government research institutes: A bottom-up dataenvelopment analysis approach," Journal of Informetrics, vol. 9, pp. 942-953, 2015.

[15] K. Leitneri, J. Prikoszovits, M Schaffhauser-Linzatti, R. Stowasser, and K. Wagner, "The impact of size and specialisation on universities' department performance: A DEA analysis applied to Austrian universities," Higher Education, vol. 53, pp. 517-538, 2007.

[16] Y. J. Fenga, H. Lua, and K. Bib, "An AHP/DEA method for measurement of the efficiency of R\&D management activities in universities," International Transactions in Operation Research, vol. 11, pp. 181-191, 2004

[17] R. Li, Y. Li, and Z. Cui, "Application of data envelopment analysis to efficiency evaluation on R\&D input and output," The Open Automation and Control Systems Journal, vol. 6, pp. 194-199, 2014.

[18] B. Kim and H. Oh, "An effective R\&D performance measurement system: survey of Korean R\&D researchers," International Journal of Management Science (Omega), vol. 30, pp. 19-31, 2002.

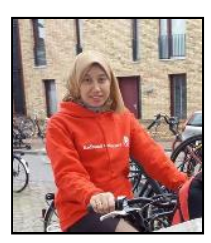

Indri Juwita Asmara was born in Medan, on January 4, 1981. She received her bachelor of computer science, University of Indonesia in 2004 and the master of information technology, Faculty of Computer Science, University of Indonesia in 2012, Jakarta Indonesia. The mother of three children, has been pursuing the world of research since 2005 at the Research Center for Development of Science and Technology (Pappiptek-LIPI). Her research area includes science and technology 
indicators, science and technology management, science and technology modeling, STI forecasting, and science and technology policies. At present the focus of his research is more towards Indonesian Science and Technology HR. Research activities from 2013 to the present are: (1) National Science and Technology Indicators, 2013. (2) S \& T Indicator Country Report presented in: Vietnam NISTPASS Study Visit in Indonesia, 2014. (3) Absorption Capacity in low-tech intensity industries, 2013 . (4) Technological Capability Upgrading and Entrepreneurship: for Joint research with Economic Research, Institute for ASEAN and East Asia (ERIA), 2013. (5) Readiness of low technology intensity industries facing the ASEAN Economic Community, 2014. (6) Science and Technology HR scenario analysts Indonesia 2025, 2015. 7) Stock and mobility of Indonesian Science and Technology HR, 2016. (8) Dynamic competency model of science and technology HR in Indonesian development, 2017. (9) Science and Technology HR in case study research institutions: Indonesian Institute of Sciences, 2018.

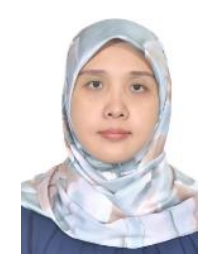

EImi Achelia was born in Jakarta in 1984. She received her bachelor in computer science from Institut Pertanian Bogor (IPB) in 2005 and the magister in information technology from University of Indonesia in 2012 .

Elmi is a researcher in research center for Development of Science and Technology, Indonesia Institute of Science (LIPI). Joined with LIPI since 2006. Currently focus in science and technology policy research, specifically in forecasting science and technology resources using System Dynamics method. Also interested in research at field of computer science and information technology, as well as previous research field in data mining and big data visualization.

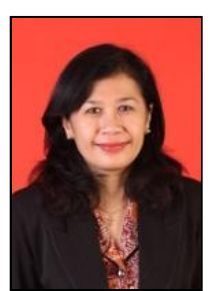

Nani Grace Berliana was born in Jakarta on October 24th, 1966. First earned a bachelor's degree, majoring in Mathematics at University of Indonesia - Indonesia, in 1985. Second, the master degree on Women Studies at University of Indonesia in 1998.

She has worked for more than 20 years at Research Center for Development of Science and Technology Indonesian Institute of Sciences.

She was a head of sub division of research cooperation on 2000 until 2002; the head of sub-field of
Measurement and Science and Technology Parameters on 2002 until 2010; Head of Information Systems and Management of Science and Technology on 2011 until 2014 and Head of Research and Dissemination Research Division on 2014 until 2017. Since 2002 to date, she is a researcher in business R\&D and innovation, conducting measurement or R\&D and innovation. During the last four years doing research on the modeling of Science and Technology Human Resource. Dra. Nani Grace Simamora, M. Hum has some scientific publications include Indonesian S\&T Indicators, Jakarta, LIPI Press, 2015; The Atlas of Islamic World Science and Innovation country Case Study Indonesia, Turki, OIC, 2014. Science and Technology in Indonesia-in Brief, Jakarta, Pappiptek, 2014. Study on the Status Science \& Technology Development in Indonesia, 2012. PAPPIPTEK-LIPI; Study on Implementation and Utilization of Mini / Micro Hydro Power Plants (PLTMH) for Increasing Productive Enterprises of Rural Communities, LIPI Press, 2010.

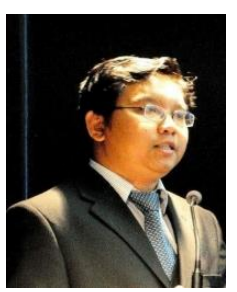

Bagus Sartono is an education doctor of philosophy (PhD), applied economics (statistics) in Universiteit Antwerpen from 2008 to 2012, the master of science (M.Sc.), Statistics at Bogor Agricultural University from 2000 to 2004. His research interests are experimental designs, data mining (ensemble approach), data mining (high dimensional regression), business intelligence.

$\mathrm{He}$ is a lecturer in some courses at Bogor Agricultural University in Statistical Theory 1, 2, simulation statistics, statistical data management, classification modeling, and analysis statistics. 